\title{
OFFER OF SAIL TRAINING \\ IN THE WEST POMERANIAN PROVINCE \\ IN THE LIGHT OF THE APPLICABLE REGULATIONS
}

\section{OLEKSANDRA OSYPCHUK, ${ }^{1}$ ALEKSANDRA ŁAPKO ${ }^{2}$}

Maritime University of Szczecin, Faculty of Economics and Transport Engineering, Szczecin, POLAND

${ }^{1}$ e-mail: 0.osypchuk@am.szczecin.pl

2 e-mail: a.lapko@am.szczecin.pl

RECEIVED
ACCEPTED
JEL
CLASSIFICATION

KEYWORDS

ABSTRACT
10 August 2017

15 December 2017

L83, L88, L11, L92

sailing, nautical tourism, sailing patents, training services

The main aim of the article is to present the current situation on the market of sailing training services in the West Pomeranian Province and to answer the question whether entities that provide such services are necessary when sailing courses are not obligatory anymore.

The first part of the article presents the current regulations on the conditions for obtaining sailing license and the statistics on the number of licenses issued in 2009-2016. Then the offer of selected training centers operating in the West Pomeranian Province is described. In addition to study on the supply, the authors carried out study on the demand. This concerned the reasons why respondents chose to attend a sailing course.

\section{Introduction}

Sailing is often described as an example of qualified tourism (Lewczuk, 2009; Lubański, 2005; PawlikowskaPiechotka, 2003; Piasecki, 2016). According to the definition proposed by T. Łobożewicz (1983, p. 8) qualified tourism is a highly specialized form of tourism, which requires proper preparation from its practitioners. To qualify for this type of tourism, it is often necessary to have a document issued by a competent organization that will confirm 
the person's ability. When sailing is concerned, appropriate skills are required only from people who have the yacht they intend to sail, although not always. According to the law currently in force in Poland, a yacht up to $7.5 \mathrm{~m}$ in length can be operated without any license. However, it is difficult to disagree with the statement by J. Gospodarek, who notes that sailing is a special form of water tourism and is related to the fulfillment of specific conditions and restrictions resulting from the need to ensure the safety of those who sail (Gospodarek, 2007, p. 151). Every year, many people decide to take sailing license exams, thus gaining the certification to operate their own yachts. These exams are, in principle, a confirmation of their knowledge and skills. It raises the question that becomes a research problem of how they can be passed and whether specialized training centers are needed to do that. In order to solve the problem, there is a need to verify the research hypothesis, which says that changes in legal regulations do does not present a threat for a position of the training centers.

The first part of the article discusses the current regulations governing the rules for awarding sailing licenses.

Then, the statistics on the number of licenses issued by the Polish Yachting Association (PYA) and the offer of selected sailing training centers operating in the West Pomeranian province are presented.

In the next part of the paper the results of a survey conducted among participants in sailing courses organized by selected training centers are presented.

\section{Legal basis for sailing tourism}

In Poland there is no single legal act that would regulate all the major issues related to sailing. Regulations in this area are often the result of general provisions on tourism, but also on the use of marine and inland waterways (Łapko, 2015, p. 36). The most important legal acts in respect to the subject of this article are:

1. Inland Waterway Act (Act, 2000), which is a normative act regulating matters related to navigation in inland waterways.

2. Sports Act of 25 June 2010, which introduces Article 37a to the Inland Waterway Act, stating that: the operation of sport or recreational craft, known as "water tourism", requires:

- possessing appropriate knowledge and skills in the field of sailing,

- adherence to safety rules for water tourism.

Article 67, para. 3 of the Sports Act contains a very important statement that practicing water tourism on sailing yachts with hull lengths exceeding $7.5 \mathrm{~m}$ or motors with an engine power exceeding $10 \mathrm{~kW}$ requires a qualification certificate or license issued by the relevant Polish sports association.

3. Regulation of the Minister of Sport of 9 April 2013 on sailing, which, as an act implementing the Inland Waterway Act provides requirements for obtaining sailing licenses on the basis of sailing exams (exam methods and fees) and license templates.

It should be noted that in the last decade regulations on the current sailing courses, the scope of their holders' rights as well as the rules regarding their obtaining have changed three times. The current regulation is the most liberal in these matters. The highest license-free requirements have been introduced. At present, yachts up to $7.5 \mathrm{~m}$ (previously $5 \mathrm{~m}$ ) can be operated without any qualifications (Act, 1996, Article 53a, para. 2). In addition, the number of sailing licenses was reduced from 4 to 3 by removing the yacht helmsman license (YH). Remaining licenses are: inland skipper (IS), yacht skipper (YS) and yacht master (YM). The liquidation of the YH license increased the rights of the IS and YS. 
Now, the IS license authorizes to operate sailing yachts in inland waterways without restrictions and yachts of hull length up to $12 \mathrm{~m}$ in internal sea waters and other marine waters in the zone up to 2 nautical miles from the coast in the daytime. This license can be obtained by a person who has turned 14 .

YS license authorizes to operate sailing yachts in inland waters and yachts of up to $18 \mathrm{~m}$ long in the sea without limitation. The license may be obtained by a person who has turned 18 and has completed at least two sea cruises of a total duration of at least 200 hours.

The YM license authorizes to operate sailing yachts in inland and marine waters without limitation.

Exams must be passed for IS and YS. The YM is awarded to a person holding a YS license, based on the experience.

The exam consists of a theoretical and practical part. Both must be credited to pass the exam. The theoretical part is a single-choice test with 75 questions, and in the case of the IS license exam, the applicant also has to solve the navigation task.

The practical part of the exam is carried out on a yacht. It checks maneuvering skills.

Although the requirement for obtaining IS and YS licenses is passing the exam, for the first time in the postwar history of Poland, the sailing course is not obligatory.

Unfortunately, it has not been possible to obtain accurate figures from the PYA, but it is known that the unchanged difficulty level of the sailing exams makes the vast majority of people taking exams participate in such courses.

While it is possible to master the theory independently and to learn the answers to the test questions, it is almost impossible to master the maneuvering skills properly. It is necessary to learn it from other people with relevant knowledge and experience in this area. In addition, preparation for the practical part of the exam requires access to the yacht.

For this reason, despite the non-obligatory sailing training, there are still many sailing schools on the market and the sailing courses they organize are still popular.

\section{Statistics on the number of sailing licenses issued}

The liberalization of the rules on sailing, did not contribute to reducing the number of people willing to acquire sailing licenses. The change in the existing rules on sailing licenses in 2013 makes it difficult to make clear comparisons with previous years, so the data are presented in two tables. At the same time, it is pointed out that the data covers the entire country, and therefore all the naval districts, since no more detailed information could be obtained from the PYA, which would concern only nautical areas of the West Pomeranian Province.

Table 1 shows the number of licenses issued between 2009 and 2011, when the Regulation of the Minister of Sport of 9 June 2006 on sailing was in force (Journal of Laws, 2001, No 81, item 889, as amended). The exams were obligatory for the IS and YH. Sadly, it was impossible to obtain data from earlier periods. Table 1 shows that the number of licenses issued was relatively stable, with much more IS than $\mathrm{YH}$ licenses issued. The share of $\mathrm{YH}$ licenses in the total number of licenses issued in the analyzed years, however, increased and amounted to: $11.86 \%$ in $2009,13.99 \%$ in 2010 and $16.67 \%$ in 2011.

Table 1 does not provide data for 2012 because the current regulation has expired and new ones have not yet entered into force, which resulted in the fact that for 9 months there were no provisions specifying the detailed conditions for sailing licenses. 
Table 1. Sailing licenses issued in 2009-2011 in Poland

\begin{tabular}{cccc}
\hline \multirow{2}{*}{ Year } & \multicolumn{3}{c}{ License } \\
\cline { 2 - 4 } & IS & YH & Total \\
\hline 2009 & 11,177 & 1,504 & 12,681 \\
2010 & 10,806 & 1,758 & 12,564 \\
2011 & 10,325 & 1,722 & 12,047 \\
\hline
\end{tabular}

Source: data of the PYA.

Table 2 shows the number of licenses for IS and YH issued by the PYA in the years 2013-2016, i.e. during the period of validity of the regulation of 9 April 2013 on sailing. According to the data presented, it was only in 2015 that fewer licenses were issued than in previous years, while the record year was 2014.

It is evident that, despite the fact that still more IS licenses were issued, the share of YS licenses was greater than in 2009-2011.

It amounted to: $44.32 \%$ in $2013,42.9 \%$ in $2014,33.08 \%$ in 2015 and $25.51 \%$ in 2016 .

Table 2. Sailing licenses issued in 2013-2016 in Poland

\begin{tabular}{cccc}
\hline \multirow{2}{*}{ Year } & \multicolumn{3}{c}{ License } \\
\cline { 2 - 4 } & IS & YS & total \\
\hline 2013 & 7,287 & 5,802 & 13,089 \\
2014 & 9,499 & 7,137 & 16,636 \\
2015 & 8,056 & 3,983 & 12,039 \\
2016 & 10,803 & 3,700 & 14,503 \\
\hline
\end{tabular}

Source: data of the PYA.

For a better illustration this is shown in Figure 1, where the visible trend line shows the increase in the number of IS licenses issued and the decrease in the number of YS licenses issued.

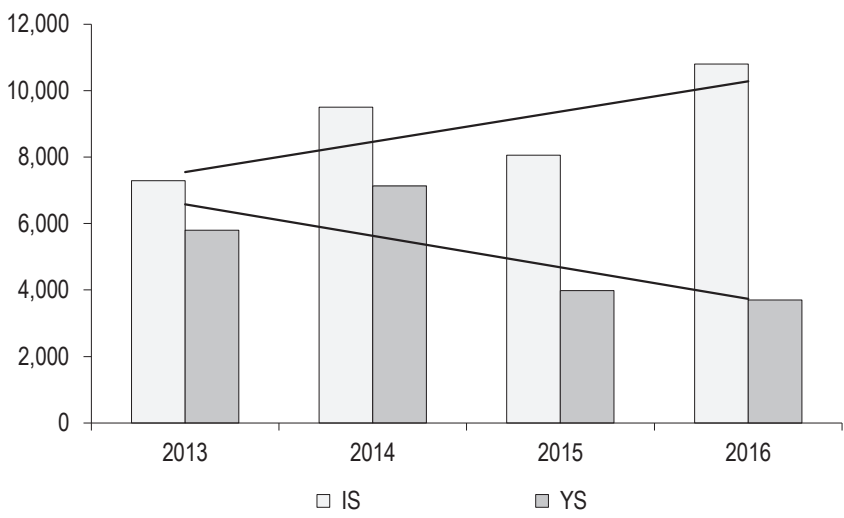

Figure 1. Number of sailing licenses issued in 2013-2016

Source: own study based on data of the PYA. 
Apparently it may seem that the data presented for 2013-2016 shows that more and more people are trying to obtain sailing licenses, especially when it comes to YS license. According to figures, despite the falls in 2015 and 2016 there were nearly twice as many applicant as in 2009-2011. Probably, however, such a large number of YS licenses issued in 2014 and 2015 resulted not only from the fact that more people took exams, but also from the fact that the licenses issued under the old regulation were replaced by new licenses. Those who held the $\mathrm{YH}$ license, upon request and payment, could automatically obtain a YS license and gain more rights.

This would explain why in the following years there is a decrease in the number of licenses issued - the majority of people who wanted to exchange documents already did it, so the statistics show mainly those taking the exams.

\section{Training offer in West Pomeranian Province}

Since sailing courses are no longer obligatory, their organizers are not, as it was in previous years, obliged to report them to the proper sailing association. It is therefore difficult to determine the exact number of centers that are engaged in this activity. Based on the study conducted in June 2017, it was stated that in the West Pomeranian Province there could be as many as 20 of such entities.

Their offer is varied in terms of prices and the form and duration of courses. Depending on needs and skills, applicants may choose several weeks of training, intensive weekly trainings, weekend trainings, training cruises or sailing camps (Gierczyk, 2011, p. 71-72). The standard is that the fee for the exam and the issue of the license is paid separately and is not added directly to the price of the course (Łapko, 2012, p. 405).

Table 3 presents selected training centers in the West Pomeranian Province.

Table 3. Offer of selected training centers in the West Pomeranian Province

\begin{tabular}{|c|c|c|c|c|c|}
\hline \multirow{2}{*}{ Training center } & \multirow{2}{*}{ City/Town } & \multicolumn{2}{|c|}{ Price (zł) } & \multirow{2}{*}{ Type } & \multirow{2}{*}{$\begin{array}{l}\text { Course } \\
\text { duration }\end{array}$} \\
\hline & & IS & YS & & \\
\hline Szkoła żeglarska Ferajna & Próchnówko & 1,350 & 1,600 & $\begin{array}{l}\text { Sailing camp; } \\
\text { Training cruise }\end{array}$ & $\begin{array}{l}14 \text { days } \\
7 \text { days }\end{array}$ \\
\hline Centrum żeglarskie & Szczecin & from 800 to 1,200 & from 900 to 1,045 & $\begin{array}{l}\text { Weekend; Intensive; } \\
\text { Stationery-holiday }\end{array}$ & $\begin{array}{l}1 \text { month } \\
14 \text { days } \\
8 \text { days }\end{array}$ \\
\hline Szkoła żeglarska Wiatr & Szczecin & 899 & 1,200 & Intensive & 7 days \\
\hline Szkoła żeglarska Wilk Morski & Kołobrzeg & 1,050 & 1,200 & Weekend; Intensive & $\begin{array}{l}1 \text { month } \\
7 \text { days }\end{array}$ \\
\hline Szkoła żeglarska Kubryk & Świnoujście & - & 1,650 & Intensive & 8 days \\
\hline Szkoła żeglarska Skagen & Kamień Pomorski & 1,000 & 1,200 & Intensive & 9 days \\
\hline
\end{tabular}

Source: own study based on http://www.ferajna.pl; centrumzeglarskie.pl; wiatr-szkola.pl; wilkmorski.pl; opensailing.com; kubryk.pl; http:/l skagen.pl (20.06.1017).

Depending on the type of course chosen, the customer decides on a particular course mode. Standard courses last from 60 to 80 hours. The theoretical part lasts no longer than 20. Training centers conduct courses according to the curriculum recommended by the PYA. Classes always cover both the theoretical and the practical part, although in different forms. 
Weekday courses are held on selected days from Monday to Friday. During the weekend course, the group meets every Saturday and Sunday. Intensive sailing courses are held daily and last from 7 to 14 days. During 7-day courses the training centers try to focus on the practical part, while theoretical part is to be mainly learned at home - participants only get access to e-learning platforms, materials in the form of textbooks and CDs, and discuss only selected topics during classes. All necessary materials for study are included in the price of the course.

Another type of course are training cruises, stationary and holiday training or sailing camps. This type of courses offer the possibility to stay on a yacht and spend most of the time on the water, for a cruise of up to 6 days (Nowacki, 2016, p. 75). The price of this type of course includes full or partial board, but often does not include e.g. port fees, yacht cleaning after the course and fuel prices.

The price of sailing courses varies depending on the type of course chosen, the amount of training material, the type of yacht or, for example, extra hours of practice. Often, training centers reduce their course fees at upcoming course dates or for the last places. In addition, most schools declare the possibility of conducting individual training or for a closed group only.

\section{Analysis of demand for participation in sailing training}

For the purpose of the article, in June 2017 the authors conducted a survey among participants of sailing courses organized by 3 selected centers operating in the West Pomeranian Province. Two of these centers are located in Szczecin and one in Kamień Pomorski. The survey was conducted with a questionnaire using direct interview technique. The questionnaire was filled by 17 participants. The purpose of the survey was to determine the reasons for the selection of the particular sailing course by respondents and the factors influencing the choice of the school. They were also asked about how to prepare for the exams for the appropriate sailing license.

There were more male respondents (71\%). The most representative age group was a group of people aged 30 to $39(41 \%)$, followed by the group of 40 to 49 yo (24\%). Youngest people up to 20 years of age accounted for only $18 \%$ of all respondents.

Most respondents trained to obtain a YS license (71\%).

To the question: Why did you attend a sailing course? most people responded that they want to: yacht themselves (94\%), improve their skills (59\%), or indicated other reasons: willingness to spend nice free time $(47 \%)$ and meet new people (29\%).

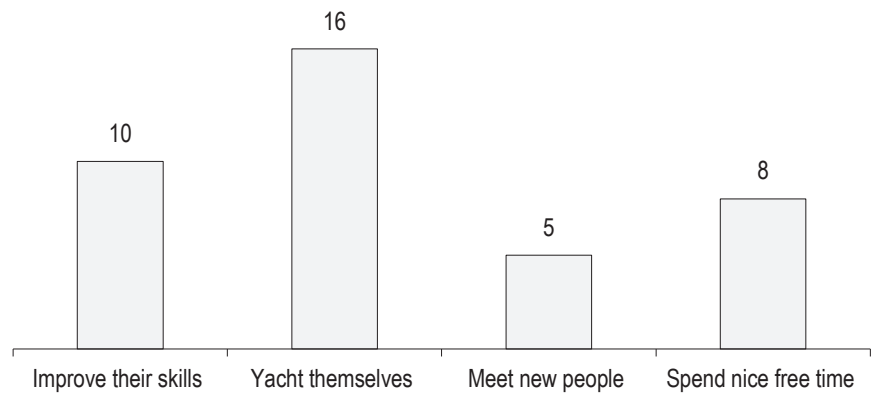

Figure 2. Reasons for attending a sailing course

Source: own study. 
The next part of the questionnaire was about preparing for the exam. According to the survey, participants do not seek for knowledge about the range of material they have to master in order to pass the exam by themselves. As many as $88 \%$ of the respondents indicated that the course material was the source of their knowledge for the preparation for the theoretical part of the exam. As far as the practical part is concerned, $100 \%$ of the respondents said that maneuvering and yachting exercises are the basic way to prepare for the exam. In addition to the course, only $6 \%$ of respondents had the opportunity to operate a yacht and practice maneuvers. Only $41 \%$ of the respondents reviewed the professional literature and $24 \%$ of the respondents used the materials available online. Only $29 \%$ of the respondents said that they were familiar with the content of the Regulation of the Minister of Sport and Tourism of 9 April 2013 on water tourism, which provides the range necessary to pass the exam.

When choosing a training center, respondents most often chose it because of the course date (59\%), proximity to training center (47\%), feedback from friends and online opinions (53\%) or used the school services earlier (24\%). Interestingly, the price of the course (12\%) was the least important reason for choosing the training center.

The results of the study show that the training material delivered during the course is often the only material used by people preparing for sailing exams. The applicants show full confidence in the training center of their choice. Although under the current regulations, sailing courses are not obligatory, they remain the simplest way to prepare for the exam. Selected knowledge, provided by professionals is the easiest to remember. The most important thing, however, is for the sailing schools to offer access to appropriate training yachts where practical training is provided. Obtaining a yacht and practicing maneuvering skills on your own is very difficult. It can therefore be said that the future of sailing schools is not threatened, although obviously a large number of these entities force owners to offer great flexibility in terms of pricing and the training methods.

\section{Conclusions}

The article presents the current situation in the market of training services in West Pomeranian province. Although in light of the current regulations governing sailing tourism and the issue of sailing licenses, no training is required before taking the sailing exam, the position of the training centers appears to be safe. The number of sailing licenses issued in Poland is growing, and most of the applicants use the services of sailing schools. They almost completely rely on the theoretical and practical knowledge provided during this type of courses. Participation in the courses provides access to the yacht, where applicants can master the maneuvering skills required for the exam.

A large number of sailing training centers force them to offer a great flexibility. This makes it easy for customers to find the one that best suits their needs and skills.

\section{Acknowledgments}

The results of the research were created within the framework of the research work entitled Badanie wybranych aspektów logistycznych turystyki żeglarskiej No. 9/S/IZT /2017 financed by subsidies from the Ministry of Science and Higher Education for the financing of statutory activities.

\section{References}

Gierczyk, Z., Ocieczek, B. (2011). Obozy turystyki kwalifikowanej formą aktywności dzieci i młodzieży. Zeszyty Naukowe Wielkopolskiej Wyższej Szkoły Turystyki i Zarządzania w Poznaniu. Studia Periegetica. Rekreacyjne i zdrowotne aspekty turystycznej aktywności człowieka, 65-76. 
Gospodarek, J. (2007). Prawo w turystyce i rekreacji. Warszawa: Difin.

http://pya.org.pl/polski-zwiazek-zeglarski.

Inland Waterway Act 21.12.2000. Journal of Laws 2013, item 1458.

Journal of Laws (2001). Physical Culture Act of 18.01.1996. Journal of Laws No 81, item 889, as amended.

Journal of Laws (2010). Sports Act of 25.06.2010. Journal of Laws No 127 item 857, as amended.

Journal of Laws (2013). Regulation of the Minister of Sport of 9.04.2013 on sailing. Journal of Laws No 0, item 460, as amended.

Lewczuk, B.(2009) Rozwój turystyki kwalifikowanej - żeglarskiej na przykładzie Szczecina. In: Z. Babińsk (ed.), Przyroda i turystyka regionu Pomorza i Kujaw. Rewitalizacja drogi wodnej Wisła-Odra szansą dla gospodarki regionu (pp. 59-67). Bydgoszcz: BDW MARGRAFSEN S.c.

Lubański, K. (2005). Wpływ środowiska rodzinnego na aktywność młodzieży w zakresie turystyki kwalifikowanej. Turystyka i Rekreacja, $1,151-156$.

Łapko, A. (2012). Żeglarskie usługi szkoleniowe na przykładzie oferty województwa zachodniopomorskiego. Zeszyty Naukowe Uniwersytetu Szczecińskiego. Ekonomiczne Problemy Usług, 96, 395-408.

Łapko, A. (2015). Turystyka żeglarska. Warszawa: BEL Studio.

Łobożewicz, T. (1983). Turystyka kwalifikowana. Warszawa: PTTK "Kraj”

Nowacki, M. (2016). Turystyka żeglarska. In: A. Stasiak, J. Śledzińska, B. Włodarczyk (eds.), Wczoraj, dziś i jutro turystyki aktywnej i specjalistycznej (pp. 75-87). Warszawa: PTTK "Kraj".

Pawlikowska-Piechotka, A. (2003). Atrakcyjność inwestycji turystycznych a walory środowiska. Problemy Ekologii, 3 (7), $136-141$.

Piasecki, W., Kliszewski, L. (2016). Rozwój żeglarstwa w lewobrzeżnej części Szczecina. Część I. Sekcja Żeglarska KS „Świt” Skolwin. Przegląd Zachodniopomorski, 4, 175-217.

Cite this apticle as: Osypchuk, O., Łapko, A. (2018). Offer of sail training in the West Pomeranian Province in the light of the applicable regulations. European Journal of Service Management, 2 (26), 167-174. DOI: 10.18276/ejsm.2018.26-21. 